\section{Journal of Environmental \& Public Health Law}

Volume 6 Issue 1

Winter 2011

\section{ARTICLES}

A Remedy in Sight:

International Clinical Research

Regulation in the Wake of

Guatemala and Nigeria

Steven W. Postal and Robyn

Whipple Diaz

Striving for Greenhouse Gas

Mitigation and Energy

Independence in Pennsylvania

Jon Johnson

\section{NOTES}

Smart Home Technology for the Elderly and the Need for

Regulation

Jessica Cocco

West Virginia's Alternative and

Renewable Energy Portfolio

Act: The "Mountain State's"

Latest Attempt to Quit its

Addiction to Coal

Alexander R. Paalborg 


\section{Journal of Environmental}

and Public Health Law

\section{Volume 6 Issue 1}

Winter 2011

The Pittsburgh Journal of Environmental and Public Health Law (PJEPHL) is published annually by students of the University of Pittsburgh School of Law, in collaboration with the Graduate School of Public Health, 3900 Forbes Avenue, Pittsburgh, PA 15260. PJEPHL can be contacted by email at pjephl@pitt.edu. Information can also be obtained online at http://pjephl.law.pitt.edu. PJEPHL is printed by Western Newspaper Publishing Co., Inc., Indianapolis, Indiana.

Single copies of Volume 6, Issue 1 are $\$ 10.00$ and are available from PJEPHL.

\section{INFORMATION FOR CONTRIBUTORS}

The Editors invite the submission of unsolicited manuscripts for publication. Submissions will be reviewed based on the following criteria: appropriateness of topical subject matter to both the overall Journal and specific volume focus, the novelty of the issue raised, the scope of the area covered, the relevance to the broader legal community as well as southwestern Pennsylvania, and the completeness and usability of the material as presented. Please confine the author's name and biographical information to a removable title page. Footnotes should conform to the 19th edition of The Bluebook: A Uniform System of Citation.

Manuscripts can be submitted electronically or in any easily readable format to Articles Editors, Pittsburgh Journal of Environmental and Public Health Law, 3900 Forbes Avenue, Pittsburgh, PA 15260. Manuscripts will not be returned. 
Volume 6 Issue 1

Winter 2011

\section{Editor-in-Chief}

TARA TIGHE

\section{Executive Editor \\ LACEE ECKER
Development Editors
CAROLINE BANISTER
TRACY LIN

Senior Topics Editor

JESSICA COCCO

\section{Subscriptions Editor}

MatTHew KelLy

\begin{abstract}
MATTHEW AlLEN Megan Crouch

Daniel Ellis

NOAH JORDAN

REBECCA LIPUT

BRYAN MURRAY

SARAH PAgan
\end{abstract}

CAROLINE Tongarm

Faculty Advisors

EMILY A. Collins

Stella L. SMETANKa

PATRICIA M. SWEENEY

\section{Senior Development} Editor

ROBERT STEIN

\section{Managing Editors \\ KeLly MISKOWSKI \\ JOE SCHAEFFER}

Topics Editors

Justin CASELLA

DURWIN FULLER

JOANNE KILGOUR

E. VRYCE HOUGH

\section{Staff Editors}

ANDREW BARBER Deborah CRum JADA GREENHOWE AMAN KAKAR Alexandra Malatesta JOSHUA NEW

LATOYA SAWYER LATI WeLlS

Office Manager; Director, Document Technology Center LUANN M. DRISCOLL
Senior Managing Editor Uzoma OgBonna

\section{Senior Articles Editor} LAURA Unger

Articles Editors

David McCANDLESS RebecCa Lebowitz NICK SCHAFER ZACH ZAGGER

Subscriptions Staff MALLORIE MCCuE CORRIE THEARLE

Daniel Baumann AleXandRa CunNingham PRESTON JAQUISH RYAN KIRAY HALSTEAD MORROW Michael OVENS SOPHIE SENYO

Document Technology Staff Phyllis GeNTILLE KAREN KNOCHEL

DarleEn A. Mocello BARB SALOPEK 


\section{UNIVERSITY OF PITTSBURGH ADMINISTRATION AND FACULTY OF THE SCHOOL OF LAW}

MARK A. NORDENBERG, Chancellor and Distinguished Service Professor of Law. B.A., Thiel College; J.D., University of Wisconsin.

MARY CROSSLEY, Dean and Professor of Law. B.A., University of Virginia; J.D., Vanderbilt University. DREW CHELOSKY, Director of Development. B.A., Washington and Jefferson College; M.P.P.M., University of Pittsburgh.

KEVIN DEASY, Associate Dean of Students and Associate Professor of Legal Writing. B.A., Pennsylvania State University; M.S.W., J.D., University of Pittsburgh.

MARLON L. FERGUSON, Director of Administration. B.A., University of Pittsburgh.

ANTHONY C. INFANTI, Associate Dean for Academic Affairs and Professor of Law. B.A., Drew University; J.D., University of California, Berkeley; LL.M., New York University.

CHARMAINE McCALL, Assistant Dean for Admissions and Financial Aid. B.A., M.B.A., University of Pittsburgh.

LORI E. McMASTER, Director of Career Services. B.A., Allegheny College; J.D., University of Pittsburgh.

GEORGE H. PIKE, Director of Barco Law Library and Assistant Professor of Law. B.A., College of Idaho; J.D., University of Idaho; M.L., University of Washington Graduate School of Library and Information Science.

\section{FACULTY AND LIBRARIANS}

JESSIE ALLEN, Assistant Professor of Law. B.F.A., New York University; J.D., Brooklyn University; J.S.D., Columbia University.

KEVIN D. ASHLEY, Professor of Law. B.A., Princeton University; J.D., Harvard University; M.A., Ph.D., University of Massachusetts.

KRISTEN BAGINSKI, Faculty Research Services Librarian. B.A., Washington and Jefferson College; J.D., Pennsylvania State University; M.L.I.S., University of Pittsburgh.

ELENA A. BAYLIS, Associate Professor of Law. B.A., University of Oregon; J.D., Yale University.

DEBORAH L. BRAKE, Professor of Law. B.A., Stanford University; J.D., Harvard University.

RONALD A. BRAND, Professor of Law and Director of the Center for International Legal Education. B.A., University of Nebraska; J.D., Cornell University.

DOUGLAS M. BRANSON, W. Edward Sell Chair in Business Law. B.A., University of Notre Dame; J.D., Northwestern University; LL.M., University of Virginia.

BENJAMIN E. BRATMAN, Associate Professor of Legal Writing. B.A., University of Washington; J.D., Vanderbilt University.

TERESA K. BROSTOFF, Director of the Legal Writing Program and Professor of Legal Writing. B.S., J.D., University of Pittsburgh.

WILliam J. BROWN, Professor Emeritus of Law. B.A., Seton Hall University; LL.B., Catholic University of America; LL.M., Yale University; Certificate in International Business Law, City of London College.

JOHN M. BURKOFF, Professor of Law. A.B., J.D., University of Michigan; LL.M., Harvard University. 
Volume 6 Issue 1

Winter 2011

NANCY M. BURKOFF, Assistant Professor of Legal Writing. A.B., University of Michigan; J.D., University of Pittsburgh.

PAT K. CHEW, Professor of Law. A.B., Stanford University; J.D., M.Ed., University of Texas.

EMILY A. COLLINS, Clinical Assistant Professor of Law. B.A., New York University; J.D., Pace University.

VIVIAN CURRAN, Professor of Law. B.A., University of Pennsylvania; Ph.D., J.D., Columbia University.

RICHARD DELGADO, Distinguished Professor Emeritus of Law. A.B., University of Washington; J.D., University of California, Berkeley.

MIRIT EYAL-COHEN, Assistant Professor of Law. S.J.D., University of California at Los Angeles; L.L.M., L.L.B., Tel-Aviv University.

JAMES L. FLANNERY, Associate Professor of Legal Writing. B.A., Miami University; Master of Urban and Regional Planning, Virginia Polytechnic Institute and State University; J.D., University of Pittsburgh.

HARRY MARSHALL FLECHTNER, Professor of Law. A.B., M.A., J.D., Harvard University.

CYRIL A. FOX, JR., Professor Emeritus of Law. A.B., College of Wooster; J.D., University of Pittsburgh.

LAWRENCE A. FROLIK, Professor of Law. B.A., University of Nebraska; J.D., LL.M., Harvard University.

DAVID J. GARROW, Research Professor. B.A., Wesleyan University; M.A., Ph.D., Duke University.

JASMINE B. GONZALES ROSE, Assistant Professor of Law. B.A., University of Oregon; J.D., Harvard

University.

HARRY J. GRUENER, Clinical Assistant Professor of Law. B.A., J.D., University of Pittsburgh.

HAIDER ALA HAMOUDI, Assistant Professor of Law. B.S., Massachusetts Institute of Technology; J.D., J.S.D.,

Columbia University.

ROBERT BERKLEY HARPER, Professor Emeritus of Law. B.S., J.D., University of Pittsburgh.

DAVID A. HARRIS, Associate Dean for Research and Professor of Law. B.A., Northwestern University; J.D., Yale University; LL.M., Georgetown University.

ARTHUR D. HELLMAN, Sally Ann Semenko Endowed Chair. B.A., Harvard University; J.D., Yale University.

DAVID J. HERRING, Co-Director of Clinic Programs and Professor of Law. B.B.A., J.D., University of Michigan.

BERNARD J. HIBBITTS, Professor of Law. B.A., Dalhousie University; M.A., Carleton University; B.A., M.A., Oxford University; LL.B., Dalhousie University; LL.M., University of Toronto; LL.M., Harvard University.

CHARLES C. JALLOH, Assistant Professor of Law. B.A., Guelph University; Bachelor of Laws and Bachelor of Civil Law, McGill University; Master's in International Human Rights Law, Oxford University.

SUSANNA M. LEERS, Electronic Research and Technology Services Librarian. B.A., Columbia University; M.A., Clark University; M.L.I.S., M.L.S., M.S.L., University of Pittsburgh.

JULES LOBEL, Professor of Law. B.A., New York University; J.D., Rutgers University.

WILLIAM V. LUNEBURG, JR., Professor of Law. B.A., Carleton College; J.D., Harvard University.

MICHAEL J. MADISON, Professor of Law. B.A., Yale University; J.D., Stanford Law School.

MARGARET M. MAHONEY, Professor of Law. B.A., LeMoyne College; J.D., University of Michigan.

MARTHA M. MANNIX, Co-Director of Clinic Programs and Clinical Associate Professor of Law. B.A., University of Vermont; J.D., University of California, Hastings.

FRANCIS BARRY McCARTHY, Professor of Law. A.B., Stonehill College; J.D., Boston College; LL.M., Columbia University. 
ALAN MEISEL, Professor of Law and Dickie, McCamey \& Chilcote Professor of Bioethics. B.A., J.D., Yale University.

PETER B. OH, Associate Professor of Law. B.A., Yale University; J.D., University of Chicago.

PATRICIA A. RONCEVICH, Acquisitions/Serials Librarian. B.A., M.L.S., University of Pittsburgh.

THOMAS ROSS, Professor of Law. B.A., J.D., University of Virginia.

RICHARD HARRY SEEBURGER, Professor Emeritus of Law. A.B., Dickinson College; LL.B., LL.M., Harvard University.

KAREN SHEPHARD, Information Services Librarian. B.A., Grove City College; M.L.I.S., University of Pittsburgh.

MARC B. SILVERMAN, Associate Director for Public Services. B.F.A., Ohio University; M.L.S., M.A., University of Pittsburgh.

ANN SINSHEIMER, Professor of Legal Writing. B.A., M.A., University of Michigan; J.D., University of Pittsburgh.

STELLA L. SMETANKA, Clinical Professor of Law. B.A., Carlow College; J.D., University of Pittsburgh.

SALLIE SMITH, Cataloging/Systems Librarian. B.S., Villa Maria College; M.L.S., Syracuse University; M.L.S., M.S.L., University of Pittsburgh.

JEAN STEFANCIC, Research Professor Emerita of Law. B.A., Maryville College; M.A., University of San Francisco.

LINDA TASHBOOK, Foreign, International and Comparative Law Librarian. B.S., Texas Woman's University; M.L.S., J.D., University of Pittsburgh.

GEORGE H. TAYLOR, Professor of Law. B.A., Brown University; M.A., University of Chicago; J.D., Harvard University.

JUDITH A. TEETER, Visiting Assistant Professor of Law. B.A., University of Wisconsin; J.D., Boston University; Master's Certificate in Conflict Resolution, Duquesne University.

SHEILA I. VELEZ-MARTINEZ, Visiting Clinical Assistant Professor of Law. B.A., J.D., University of Puerto Rico.

LU-IN WANG, Professor of Law. B.S., Pennsylvania State University; B.A., University of Pittsburgh; J.D., University of Michigan.

RHONDA WASSERMAN, Professor of Law. A.B., Cornell University; J.D., Yale University.

\section{AFFILIATED FACULTY}

DAVID BARNARD, Professor, Department of Medicine, School of Medicine; Affiliated Professor, School of Law. B.A., University of Chicago; M.A., Brandeis University; M.T.S., Harvard Divinity School; Ph.D., Harvard University; J.D., University of Pittsburgh.

ROBERT M. HAYDEN, Professor, Department of Anthropology, School of Arts and Sciences; Affiliated Professor, School of Law. B.A., Franklin and Marshall College; M.A., Syracuse University; J.D., Ph.D., State University of New York at Buffalo.

KENNETH M. LEHN, Samuel A. McCullough Professor of Finance, Katz Graduate School of Business; Affiliated Professor, School of Law. B.A., Waynesburg College; M.A., Miami University; Ph.D., Washington University. 
Volume 6 Issue 1

Winter 2011

JEFFREY J. SHOOK, Assistant Professor, School of Social Work; Affiliated Assistant Professor, School of Law. B.A., Grinnell College; J.D., American University; M.S.W., Ph.D., University of Michigan.

\section{ADJUNCT FACULTY}

KEVIN C. ABBOTT, Adjunct Professor of Law. B.A., Indiana University of Pennsylvania; J.D., University of Pittsburgh.

RODNEY R. AKERS, Adjunct Professor of Law. B.A., University of Virginia; J.D., Harvard University.

CARRIE L. ALLMAN, Adjunct Professor of Law. B.A., Ohio Wesleyan University; J.D., University of Pittsburgh.

LYNN J. ALSTADT, Adjunct Professor of Law. B.S., B.A., J.D., University of Pittsburgh.

THOMAS D. ARBOGAST, Adjunct Professor of Law. B.A., West Virginia University; J.D., Duquesne University.

STEVEN F. BAICKER-McKEE, Adjunct Professor of Law. B.A., Yale University; J.D., College of William and Mary.

ROBERT S. BARKER, Adjunct Professor of Law. B.A., J.D., Duquesne University.

EDWIN H. BEACHLER, Adjunct Professor of Law. B.A., Georgetown University; J.D., University of Pittsburgh.

JACLYN M. BELCZYK, Adjunct Professor of Law. B.A., J.D., University of Pittsburgh.

C. ALLEN BLACK, JR., Adjunct Professor of Law. B.A., University of Alabama; Ph.D., University of Newcastle (Australia); J.D., University of Pittsburgh.

DONALD C. BLUEDORN, II, Adjunct Professor of Law. B.S., Grove City College; J.D., University of Pittsburgh.

EDWARD J. BORKOWSKI, Adjunct Professor of Law. B.A., J.D., Duquesne University; M.S.W., University of Pittsburgh.

EDUARDO H. BOZZO, Adjunct Professor of Law. B.A., National School of Commerce (Buenos Aires, Argentina);

J.D., University of Argentina.

ROBERT MARC BRENNER, Adjunct Professor of Law. A.B., Stanford University; J.D., Yale University.

TYBE A. BRETT, Adjunct Professor of Law. B.A., Barnard College; J.D., Columbia University.

KIMBERLY A. BROWN, Adjunct Professor of Law. B.A., University of Dayton; J.D., Duke University.

SARA BURHAN ABDULLAH, Adjunct Professor of Law. J.D., LL.M., University of Pittsburgh; L.L.B., University of Sulaymania (Iraq).

CHARLES C. COHEN, Adjunct Professor of Law. A.B., Dartmouth College; J.D., University of Michigan.

JOHN C. CONTI, Adjunct Professor of Law. B.A., University of Pittsburgh; J.D., Duquesne University.

MARIA GRECO DANAHER, Adjunct Professor of Law. B.S., Indiana University; J.D., University of Pittsburgh.

ELLIOT DATER, Adjunct Professor of Law. B.A., J.D., University of Michigan.

CLAUDIA DAVIDSON, Adjunct Professor of Law. B.A., State University of New York (Buffalo); J.D., Rutgers

University (Newark)

MARSHALL L. DAYAN, Adjunct Professor of Law. B.A., University of Georgia; J.D., Antioch University.

LEON F. DeJULIUS, JR., Adjunct Professor of Law. B.S.B.A., St. Louis University; J.D., University of Notre Dame.

THE HON. JEFFERY A. DELLER, Adjunct Professor of Law. B.A., University of Pittsburgh; J.D., Duquesne University.

PATRICK J. DeMAY, Adjunct Professor of Law. B.A., University of Notre Dame; J.D., University of Pittsburgh. 
CHARLES A. De MONACO, Adjunct Professor of Law. B.A., University of Notre Dame; J.D., Ohio Northern University.

CECILE C. M. DESANDRE, Adjunct Professor of Law. Baccalaureate A2, The Sorbonne, Paris.

STEVEN A. DIAZ, Adjunct Professor of Law. B.A., San Francisco State University; J.D., Santa Clara University.

PATRICIA L. DODGE, Adjunct Professor of Law. B.S., Pennsylvania State University; J.D., Duquesne University. THOMAS J. FARRELL, Adjunct Professor of Law. B.A., Yale University; J.D., New York University. THE HON. D. MICHAEL FISHER, Adjunct Professor of Law. B.A., J.D., Georgetown University. THE HON. JUDITH FITZGERALD, Adjunct Professor of Law. B.S., J.D., University of Pittsburgh. SUSAN FRIETSCHE, Adjunct Professor of Law. A.B., Bryn Mawr College; J.D., Temple University. MICHAEL GEORGE, Adjunct Professor of Law. B.A., Bowling Green University; J.D., Duquesne University. JOHN P. GISMONDI, Adjunct Professor of Law. B.A., J.D., University of Pittsburgh.

K. MARK HALL, Adjunct Professor of Law. B.S., Michigan State University; J.D., University of Pittsburgh. KEVIN C. HARKINS, Adjunct Professor of Law. B.A., Pennsylvania State University; J.D., University of Pittsburgh.

ROBERT T. HARPER, Adjunct Professor of Law. B.A., J.D., Duke University.

LEO HITT, Adjunct Professor of Law. B.A., J.D., University of Pittsburgh; LL.M., New York University.

JOSEPH S. HORNACK, Adjunct Professor of Law. A.B., Miami University; J.D., Rutgers, The State University of New Jersey.

KENNETH J. HOROHO, JR., Adjunct Professor of Law. B.S., St. Francis College; J.D., Duquesne University. THE HON. PHILIP A. IGNELZI, Adjunct Professor of Law. B.S.B.A., University of Dayton; J.D., University of Pittsburgh.

JOHN E. IOLE, Adjunct Professor of Law. B.A., J.D., University of Pittsburgh.

STEPHEN R. KAUFMAN, Adjunct Professor of Law. B.A., Allegheny College; J.D., Harvard University.

RICHARD P. KIDWELL, Adjunct Professor of Law. B.A., Mount St. Mary's College; J.D., University of Maryland. MILES A. KIRSHNER, Adjunct Professor of Law. B.A., George Washington University; J.D., University of Pittsburgh.

GEORGE KONTOS, Adjunct Professor of Law. B.A., J.D., University of Pittsburgh.

THE HON. BETH A. LAZZARA, Adjunct Professor of Law. B.A., J.D., University of Pittsburgh.

LAWRENCE M. LEBOWITZ, Adjunct Professor of Law. B.A., University of Pennsylvania; J.D., University of Pittsburgh.

THE HON. LISA PUPO LENIHAN, Adjunct Professor of Law. B.A., J.D., University of Pittsburgh.

RICHARD C. LEVINE, Adjunct Professor of Law. B.A., J.D., University of Pittsburgh.

PENINA K. LIEBER, Adjunct Professor of Law. B.A., M.A., J.D., University of Pittsburgh.

ALEXANDER H. LINDSAY, JR., Adjunct Professor of Law. B.A., Washington and Jefferson College; J.D., University of Pittsburgh.

BLAINE A. LUCAS, Adjunct Professor of Law. B.A., University of Pittsburgh; J.D., University of Virginia. KEVIN P. LUCAS, Adjunct Professor of Law. B.A., Fordham University; J.D., University of Michigan. JOHN PATRICK LYDON, Adjunct Professor of Law. B.A., Allegheny College; J.D., University of Pittsburgh. BEVERLY WEISS MANNE, Adjunct Professor of Law. B.A., J.D., University of Pittsburgh.

JASON E. MATZUS, Adjunct Professor of Law. B.A., Gettysburg College; J.D., University of Pittsburgh. 
Volume 6 Issue 1

Winter 2011

REGIS M. McCLELLAND, Adjunct Professor of Law. B.A., J.D., Duquesne University.

DAVID L. McCLENAHAN, Adjunct Professor of Law. B.A., John Carroll University; J.D., Duquesne University.

JOHN W. McILVAINE, III, Adjunct Professor of Law. B.S., Pennsylvania State University; J.D., Pepperdine

University.

JANICE McSHERRY, Adjunct Professor of Law. A.B., Colgate University; J.D., University of Pittsburgh.

LAURA A. MEADEN, Adjunct Professor of Law. B.A., Case Western Reserve University; J.D., University of Pittsburgh.

CHARles H. MOEllenberG, JR., Adjunct Professor of Law. B.A., Denison University; M.P.A., Princeton University; J.D., Columbia University.

J. W. MONTGOMERY, III, Adjunct Professor of Law. B.A., University of Virginia; J.D., College of William and Mary.

REBECCA E. MORRIS-CHATTA, Adjunct Professor of Law. B.A., M.P.H., University of Washington; J.D., University of Pittsburgh.

DEBORAH D. OLSZEWSKI, Adjunct Professor of Law. B.A., J.D., University of Pittsburgh; M.A., Edinboro State College.

MICHAEL J. PANELLA, Adjunct Professor of Law. B.S., University of Michigan; M.D., Medical College of Pennsylvania; J.D., University of Pittsburgh.

DIANE W. PERER, Adjunct Professor of Law. A.B., Vassar College; J.D., University of Pittsburgh.

JON R. PERRY, Adjunct Professor of Law. B.A., Pennsylvania State University; J.D., Duquesne University.

STEPHEN M. PINCUS, Adjunct Professor of Law. A.B., University of Michigan; J.D., University of Maryland.

LINDA PINGITORE, Adjunct Professor of Law. B.S., J.D., University of Pittsburgh.

ELIZABETH J. POGGI, Adjunct Professor of Law. B.A., Wheaton College; J.D., Duquesne University.

J. MATTHEW PRITCHARD, Adjunct Professor of Law. B.S., Carnegie Mellon University; J.D., University of Pittsburgh.

JEFFREY A. RAMALEY, Adjunct Professor of Law. B.A., University of Pittsburgh; J.D., Duquesne University. ROBERT B. RAMSEY, III, Adjunct Professor of Law. B.A., University of Delaware; J.D., St. Louis University. DIXON R. RICH, JR., Adjunct Professor of Law. B.S., Lehigh University; J.D., Duquesne University.

D. WES RIST, Adjunct Professor of Law. B.A., Bob Jones University; J.D., University of Pittsburgh; LL.M., University of the West of England.

MiCHAEL J. ROESCHENTHALER, Adjunct Professor of Law. B.A., The Pennsylvania State University; J.D., University of Pittsburgh.

DAVID J. ROSENBERG, Adjunct Professor of Law. B.A., Connecticut College; J.D., University of Pittsburgh.

MICHAEL H. ROSENZWEIG, Adjunct Professor of Law. B.A., J.D., University of Pittsburgh.

JOHN S. ROZEL, Adjunct Professor of Law. A.B., M.D., Brown University; M.S.L., University of Pittsburgh.

ODAY SALIM, Adjunct Professor of Law. B.A., J.D., Wayne State University; LL.M., Lewis \& Clark University.

JENNIFER SATLER, Moot Court Program Coach. B.A., Bryn Mawr College; J.D., University of Pittsburgh.

LINDA F. SCHNEIDER, Adjunct Professor of Law. B.S., M.B.A., J.D., University of Pittsburgh.

THEODORE A. SCHROEDER, Adjunct Professor of Law. B.A., J.D., University of Pittsburgh.

VIRGINIA SPENCER SCOTT, Adjunct Professor of Law. B.A., Allegheny College; J.D., University of Pittsburgh. 
JOSEPH W. SELEP, Adjunct Professor of Law. B.A., Indiana University of Pennsylvania; J.D., Ohio Northern University.

LARRY A. SILVERMAN, Adjunct Professor of Law. B.A., University of Pittsburgh; J.D., Duquesne University. JENNIFER A. SMOKELIN, Adjunct Professor of Law. B.S.E., University of Pennsylvania; J.D., University of Pittsburgh.

W. HENRY SNYDER, Adjunct Professor of Law. B.A., University of Washington; J.D., Willamette University; LL.M., New York University.

STEVEN M. STADTMILLER, Adjunct Professor of Law. B.B.A., University of Notre Dame; J.D., University of Pittsburgh.

JOHN STEMBER, Adjunct Professor of Law. B.A., Ohio University; J.D., University of Pittsburgh.

NATALYA STEPANOVA-SIPPER, Adjunct Professor of Law. J.D., Tashkent State Law Institute; M.L., University of Pittsburgh.

EDWARD VAN STEVENSON, JR., Adjunct Professor of Law. B.A., Kentucky State University; J.D., University of Kentucky.

ALICE STEWART, Adjunct Professor of Law. J.D., Duquesne University.

JOHN STINSON, Adjunct Professor of Law. B.A., Radford University; M.A., Bowling Green State University; J.D., University of Toledo; LL.M., Goethe Universitaet Frankfurt am Main (Germany).

JAN C. SWENSEN, Adjunct Professor of Law. B.S., J.D., University of Pittsburgh.

THE HON. DAVID B. TORREY, Adjunct Professor of Law. A.B., West Virginia University; J.D., Duquesne University.

MARK V. TRANQUILLI, Adjunct Professor of Law. B.A., Allegheny College; J.D., University of Pittsburgh.

CHATÓN T. TURNER, Adjunct Professor of Law. B.A., University of Virginia; J.D., University of South Carolina. JAMES S. URBAN, Adjunct Professor of Law. B.A., University of Pittsburgh; J.D., Duquesne University.

DAVID W. WAGNER, Adjunct Professor of Law. B.S., Pennsylvania State University; M.A., The George Washington University; J.D., American University.

PETER M. WATT-MORSE, Adjunct Professor of Law. B.A., Carleton College; J.D., Northwestern University.

THE HON. R. STANTON WETTICK, JR., Adjunct Professor of Law. B.A., Amherst College; LL.B., Yale University.

PATRICIA HARRINGTON WYSOR, Legal Writing Center Director. B.A., Wheaton College; M.Ed., M.F.A., University of Pittsburgh.

THE HON. JOHN A. ZOTTOLA, Adjunct Professor of Law. B.A., J.D., University of Pittsburgh.

\section{ADMINISTRATIVE STAFF}

SAMANTHA H. COYNE, Employer Relations Specialist. B.A., University of Pittsburgh; M.B.A., Duquesne University.

CHRISTINA M. DAUB, Administrative Coordinator. B.A., University of Pittsburgh.

LUANN M. DRISCOLL, Office Manager and Director of the Document Technology Center.

BRIANA H. GREEN, Associate Director for D.C. Area Outreach. B.A., University of California, Santa Barbara; J.D., Catholic University of America. 


\section{Volume 6 Issue 1}

Winter 2011

JACQUELINE (JACKI) M. HERZOG, Director of Employer Recruitment. B.A., Tulane University; M.A., Washington University (St. Louis); J.D., Duquesne University.

MEME JEFFRIES, Director of Financial Aid and Assistant Director of Admissions. B.S., Pennsylvania State University; M.Ed., University of Pittsburgh.

JUSTINE KASZNICA, Director, Innovation Practice Institute. B.A., Yale University; J.D., Rutgers UniversityCamden.

MATTHEW KURPIEWSKI, Director of Information Technology. B.S., University of Pittsburgh. BETH T. LIBERATORE, Registrar.

ALEXANDRA LINSENMEYER, Director of Admissions. A.B., The College of William and Mary; M.Ed., The George Washington University.

KEELEY P. MITCHELL, Director of Public Interest and Government Relations. B.A., New York University; J.D., Georgetown University.

MEGAN O'DONNELL, Director of Communications. B.A., Allegheny College; M.P.M., Carnegie Mellon University.

ALLISON SARAS, Director of Constituent Relations. B.A., Pennsylvania State University; M.P.A., Villanova University. 


\title{
Journal of Environmental
}

and Public Health Law

Volume 6 Issue 1

Winter 2011

\section{TABLE OF CONTENTS}

\author{
ARTICLES \\ 1 Steven W. Postal and Robyn \\ Whipple Diaz \\ A Remedy in Sight: \\ International Clinical \\ Research Regulation in the \\ Wake of Guatemala and \\ Nigeria \\ 41 Jon Johnson \\ Striving for Greenhouse Gas \\ Mitigation and Energy \\ Independence in Pennsylvania
}

\section{NOTES}

85 Jessica Cocco

Smart Home Technology for the Elderly and the Need for Regulation

109 Alexander R. Paalborg

West Virginia's Alternative and Renewable Energy Portfolio Act: The "Mountain State's" Latest Attempt to Quit its Addiction to Coal 
